Lima, 31 de agosto y 1 de septiembre de 2006

\title{
Primer Taller de Historia de la ciencia colonial
}

Lima, 31 de agosto y 1 de septiembre de 2006

\section{Carmen Salazar-Soler}

\section{OpenEdition \\ Journals}

\section{Edición electrónica}

URL: http://journals.openedition.org/bifea/4713

DOI: 10.4000/bifea.4713

ISSN: 2076-5827

Editor

Institut Français d'Études Andines

Edición impresa

Fecha de publicación: 1 mayo 2006

Paginación: 234

ISSN: 0303-7495

Referencia electrónica

Carmen Salazar-Soler, « Primer Taller de Historia de la ciencia colonial », Bulletin de l'Institut français d'études andines [En línea], 35 (2) | 2006, Publicado el 08 mayo 2006, consultado el 03 diciembre 2020. URL : http://journals.openedition.org/bifea/4713 ; DOI : https://doi.org/10.4000/bifea.4713

\section{(c)}

Les contenus du Bulletin de l'Institut français d'études andines sont mis à disposition selon les termes de la licence Creative Commons Attribution - Pas d'Utilisation Commerciale - Pas de Modification 4.0 International. 


\section{PRIMER TALLER DE HISTORIA DE LA CIENCIA COLONIAL}

Lima 31 de agosto y 1 de septiembre de 2006

La Pontificia Universidad Católica del Perú ha creado desde hace unos años un espacio académico destinado a debatir temas coloniales entre especialistas peruanos y extranjeros. Este año, el Departamento de Humanidades, con el auspicio del CONCYTEC, La Embajada de Francia en el Perú, el Instituto Francés de Estudios Andinos y la Fundación Carolina, organizó el fer Taller de la ciencia colonial, que se llevó a cabo en Lima los días 31 de agosto y 1 de septiembre en el Convento de San Francisco y en el Instituto Riva Agüero respectivamente, bajo el título La circulación de ideas científicas en América colonial. Esta reunión académica tuvo como objetivo reflexionar sobre las formas de circulación del conocimiento científico en el imperio hispánico, a través de la difusión del saber europeo hacia América y de la elaboración de ideas y teorías en el espacio americano.

El evento reunió a un conjunto de especialistas internacionales sobre el tema (españoles, colombianos, franceses, brasileros y peruanos) ; y si bien el taller estuvo centrado en América colonial, se optó por una perspectiva comparativa, al contar con la participación de un historiador de la ciencia especialista de la India colonial.

Durante los dos días de reunión, la reflexión estuvo centrada en el estudio de los agentes o actores de la circulación del saber, así como también de los mecanismos y condiciones que hacen posible las circulaciones de ideas y conocimientos. Varios otros temas ocuparon la atención de los ponentes, tales como el de las relaciones entre ciencia y poder, o la captación e incorporación del saber nativo o local al corpus de conocimientos que circulaba en la época. Las ponencias presentadas pusieron también en debate la relación entre Ilustración e Independencia, así como también la noción de eurocentrismo y difusionismo. En resumen, el Taller se propuso reflexionar bajo esta perspectiva comparativa, sobre los procesos de circulación y de construcción de los conocimientos en América colonial. 